\title{
Magdalena Chmielecka
}

Uniwersytet Kardynała Stefana Wyszyńskiego w Warszawie

\section{THE ‘USUS' AS A WAY TO PUT A WOMAN UNDER THE AUTHORITY OF HER HUSBAND}

There is no doubt that issues associated with marriage are some of the most frequently addressed questions in Roman law studies, both in Polish and international scholarship. Yet there are still many problems which have not been fully examined ${ }^{1}$. Not surprisingly, explaining all the details of issues connected with marriage is holding the attention of many scholars of Roman law, because of course marriage is one of the most ancient institutions which have come down to our times; moreover, its form varies from culture to culture, and it applies to very many individuals. In view of all this, the institution of marriage offers a very interesting area of study, and the full analysis of all of its aspects seems to be very important.

The subject of this article is usus as a method whereby a woman was put under the authority of her husband.

The principal source of information on this subject are the Institutes of Gaius:

G. 1,110: Olim itaque tribus modis in manum conveniebant: usu, farreo, coëmptione.

1 See M. Kury£owicz, Wokót istoty małżeństwa rzymskiego, [in:] 'Finis legis Christus'. Księga pamiątkowa dedykowana księdzu Profesorowi Wojciechowi Góralskiemu z okazji siedemdziesiątej rocznicy urodzin, ed. J. WroceńsKI, J. KRAJCZYŃsKI, II, Warszawa 2009, p. 1141; see also W. RozWADowsKI, Istota małżeństwa w starożytnym Rzymie, «Gdańskie Studia Prawnicze» 14/2005, p. 773. 
Gaius informs us that in the old days there were three methods whereby a woman could be put under her husband's authority: usus, confarreatio, and coëmptio ${ }^{2}$. Although usus comes first in his list, that does not mean we should attribute a special significance to this. We may conjecture that it was not a chronological order, either, because usus was probably the last of the three forms of marriage to be instituted. $\mathrm{H}$. Insadowski argues that it may have been an order of importance of the three ways in which a wife could come under her husband's authority ${ }^{3}$, but his claim may be challenged.

On the grounds of the following passage from Gaius we should perhaps say that the pre-eminent means by which a wife came under her husband's authority was confarreatio:

G. 1,112: Farreo in manum conveniunt per quoddam genus sacrificii, quod Iovi Farreo fit; in quo farreus panis adhibetur, unde etiam confarreatio dicitur; complura praeterea huius iuris ordinandi gratia cum certis et sollemnibus verbis praesentibus decem testibus aguntur et fiunt. Quod ius etiam nostris temporibus in usu est: Nam flamines maiores, id est Diales, Martiales, Quirinales, item reges sacrorum, nisi ex farreatis nati non leguntur: Ac ne ipsi quidem sine confarreatione sacerdotium habere possunt.

Gaius stresses that a candidate aspiring to the senior sacerdotal offices was required to have been born to parents who had contracted marriage consolidated by confarreatio. Confarreatio was the most formal, but also the most complicated way in which a woman was made subject to the authority of her husband. The act of contracting the marriage

2 Cf. E. Volterra, La conception du mariage d'après les juristes romains, Padova 1940, p. 8; E. Cantarella, L'usus e la conventio in manum', «Labeo» 41/1995, p. 434; J.E. GRuBBs, Women and the Law in the Roman Empire, London and New York 2002, p. 21-22; L. Capogrossi Colognesi, 'Matrimonium', 'manus' e 'trinoctium', [in:] Marriage: Ideal - Law - Practice. Proceedings of a Conference Held in Memory of Henryk Kupiszewski, Warszawa 2005, p. 63-81.

3 H. Insadowski, Rzymskie prawo małżeńskie a chrześcijaństwo, Lublin 1935, p. 125. 
probably took place during the rites ${ }^{4}$, which involved a series of special formulae, though the part considered the central point of the ceremony was the offering of the panis farreus, a special kind of wheat flour bread, as a sacrifice to Jupiter (hence the name confarreatio), and the application of fire and water ${ }^{5}$. Hence confarreatio was the most official way by which a woman was put under the authority of her husband, and we may assume that originally it was reserved exclusively for patricians ${ }^{6}$.

We should note that confarreatio was still the only way a wife could pass under the manus of her husband in Gaius' times, which was due to the fact that certain priests, the flamen Dialis, Martialis, and Quirinalis, and rex sacrorum, had to be born to parents joined in confarreatio wedlock, and had to be in confarreatio marriages themselves. However, the effects of confarreatio applied only to the religious sphere ${ }^{7}$.

So perhaps Gaius put usus first in the list because it used to be the most commonly used form of convention in manum. But we should note that as a way of putting a woman under her husband's manus, usus did not require the couple to bear any expenses, nor did it involve any special conditions, and all that was needed to achieve manus status was an uninterrupted one-year period of cohabitation ${ }^{8}$.

4 See M. Zавєоска, 'Confarreatio’ w ustawodawstwie pierwszych cesarzy rzymskich, «Prawo Kanoniczne» 31.1-2/1988, p. 237-238.

5 H. Insadowski, op. cit., p. 115; M. ZaвŁocka, Przemiany prawa osobowego i rodzinnego $w$ ustawodawstwie dynastii julijsko-klaudyjskiej, Warszawa 1987, p. 95; EADEM, Confarreatio $w$ ustawodawstwie pierwszych cesarzy rzymskich, "Prawo Kanoniczne» 31.1-2/1988, p. 239-245; W. RozwADowski, Zarys wykładu wraz z wyborem źródeł, Warszawa 1991, p. 204; M. KurYŁowICz, Prawo i obyczaje w starożytnym Rzymie, Lublin 1994, p. 57; E. Cantarella, op. cit., p. 435.

6 J. Linderski, Religious Aspects of the Conflict of the Orders: The Case of 'confarreatio', [in:] Social Struggles in Archaic Rome. New Perspectives on the Conflict of the Orders, ed. K.A. RaAuflaub, Berkeley 1986, p. 542-559; W. Rozwadowski, Istota..., p. 782.

7 Tac., Ann. 4,16.

8 As W. Rozwadowski writes (Istota..., p. 782), only patricians could contract confarreatio, while coëmptio as a rule involved a considerable financial outlay. Hence usus must have been the most widely accessible form of marriage in which the wife came under the authority of the husband. 
G. 1,111: Usu in manum conveniebat, quae anno continuo nupta perseverabat; quia enim velut annua possessione usucapiebatur, in familiam viri transibat filiaeque locum optinebat.

The woman passed under her husband's manus after a year of marriage, which had to be uninterrupted ${ }^{9}$. From this passage in Gaius we have to conclude that under this form of entering the husband's power consensus, that is the initial joint consensual declaration of will ${ }^{10}$, did not constitute sufficient grounds for the validity of manus; another necessary condition was affectio maritalis for the entire year during which the husband was acquiring manus. In other words, the necessary conditions for a successful convention in manum were the spouses' joint declaration of will, and their will to remain married for the whole period needed for the husband to acquire manus over the wife ${ }^{11}$.

Here I have to add that there is a controversy among the scholars as to the time when marriage was validly contracted and hence its duration. This is an important issue, since the answer to this question would determine the point in time when the course of usus started. According to one group of scholars, the necessary condition for the effectiveness of a marriage was for the bride to be brought into the bridegroom's house (deductio in domum mariti) ${ }^{12}$, which constituted the external act of consent between the spouses and marked the beginning of their marriage. For those who hold this opinion, the necessary conditions

9 E. Volterra, La conception..., p. 12-13; A. Watson, Studies in Roman Private Law, London 1991, p. 15-16;

10 J. Zавєоскі, Zgoda matżeńska w prawie rzymskim, [in:] 'Honeste vivere’... Księga pamiątkowa ku czci Profesora Władysława Bojarskiego, ed. A. SoKAla, E. Gajda, Toruń 2001, p. 306-307.

${ }^{11}$ J. ZABŁocki, Zgoda..., p. 309; see also M. KASER, Römisches Privatrecht, München 1986, p. 258; J. ZАвŁOCKI, 'Consensus facit nuptias', [in:] Marriage. Ideal - Law - Practice. Proceedings of a Conference Held in Memory of Henryk Kupiszewski, Warszawa 2005, p. 236; M. Kuryıowicz, Wokół istoty..., p. 1143; K. K. Hersh, The Roman Wedding. Ritual and Meaning in Antiquity, Cambridge 2010, p. 23-24.

12 J. ZaвŁoскі, Zgoda..., p. 307; see also W. RozWadowski, Istota..., p. 780. 
for marriage were animus and corpus, expressed by deductio in domum mariti. The precursor of this opinion was E. Levy ${ }^{13}$.

Another view, held by P. Bonfante and E. Volterra, says that the decisive factor was simply the consent of the bride and groom. The consent did not assume a legal nature but was merely the subjective standpoint of the two individuals, giving rise to the marriage and its permanence. However, if either of the marriage partners were to change their mind and withdraw their consent, the marriage would be dissolved ${ }^{14}$. This opinion appears to be in full agreement with Ulpian's statement, Nuptias non concubitus, sed consensus facit (Consensus, not cohabitation is what makes a marriage $)^{15}$.

Currently the prevailing opinion, held by C. Ferrini, C. Longo. and E. Betti, says that the only necessary condition to make a marriage effective was affectio maritalis; however, the deductio in domum mariti ceremony was regarded as the point in time marking the start of the marriage ${ }^{16}$. On the basis of this opinion, Z. Benincasa claims that the deductio in domum mariti ceremony was a public rite which could be witnessed by third parties, and its main purpose was to demonstrate the purity of the bride, though indirectly it was also an expression of affectio maritalis ${ }^{17}$.

If we assume that the course of usus was considered to start effectively on the day the marriage was contracted, then certainly the fact that the bride was brought into the bridegroom's house was also evidence for the applicability of the institution of usus, as the resulting union

13 E. Levy, Hergang der römischen Ehescheidung, Weimar 1925, p. 67-75, see also M. KASER, op. cit., p. $72 \mathrm{ff}$.

14 P. Bonfante, Corso di diritto romano, I, Diritto di famiglie, Milano 1963, p. 261-263; see also E. Volterra, La concepion....,p. 3-5; IDEm , Lezioni di diritto Romano. Il matrimonio Romano, Roma 1960-61, p. 123-126; J. ZАвŁоскI, Zgoda..., p. 307-308; W. Rozwadowski, Istota..., p. 777.

15 D. 50,17,30. See J. ZabŁocki, 'Consensus'.., p. 240

16 C. Ferrini, Manuale di Pandette, II, Milano, 1904, p. 871; C. Longo, Diritto di famiglia, Milano 1934, p. 267; E. Betti, Diritto romano, I, Padova 1935, p. 231.

17 Z. BenINCASA, 'Deductio in domum mariti' a zawarcie 'iustum matrimonium', «Zeszyty Prawnicze»13.2/2013, p. 12; see also E. Volterra, Lezioni..., p. 142; J. ZABŁocki, 'Consensus'..., p. 240-241. 
was a marriage. Moreover, in view of the fact that the marriage as such was a fact, but not a legal state, proving that the partners had been married to each other, and further proving that there had been a manus relationship between them, was extremely important, because it affected the situation of the children of the union, and also the couple's situation in respect of property.

Gaius continues by saying that after an uninterrupted year of cohabitation, the wife passed under the manus of her husband or of his pater familias, and her status was analogous to that of a daughter. Although the institution of usus was modelled on usucapio, it cannot be said that the husband's authority over the wife was similar to his rights to a thing ${ }^{18}$. Significantly, the law on manus applied strictly to matters relating to property, but in other respects the power a husband had over his wife was not as extensive as his power over his children ${ }^{19}$. The status of a woman in a marriage involving manus differed from the status of a married woman who was not under the manus of her husband. A woman under her husband's manus was referred to as a mater familias, which was a title of honour ${ }^{20}$ associated with a number of privileges such as protection against being sold into slavery and the right to a trial before a iudicium domesticum court with members of her former family among the judges hearing the case ${ }^{21}$. The daughters-in-law of a pater

18 C. FAyer, La familia romana. Aspetti giuridici ed antiquari. Sponsalia. Matrimonio. Dote. Parte seconda, Roma 2005, p. 272-273.

19 K. Kolańczy K, Prawo rzymskie, Warszawa 2000, p. 235.

20 W. Kunkel, 'Mater familias', «RE» 14.2/1930, col. 2183 ff.; W. WoŁodKIEWICZ, 'Materfamilias', «CPH» 16.1/1964, p. 101 ff.; IDEM, Attorno al significato della nozione di 'mater familias', [in:] Studi in onore di C. Sanfilippo, III, Milano 1983, p. 735 ff.; R. FIorI, 'Materfamilias', «BIDR» 96-97/1993-1994, p. 455 ff.; P. Giunti, 'Consors vitae’. Matrimonio e ripudio in Roma antica, Milano 2004, p. 304 ff.; C. FAYER, op. cit., p. 285 ff.; M.V. SANnA, Matrimonio e altre situazioni matrimoniali nel diritto romano classico. 'Matrimonium iustum - matrimonium iniustum', Napoli 2012, p. 176 ff.; J. ZABŁocKI, Il concetto di 'mater familias' in caso di arrogazione, [in:] 'Mater familias'. Scritti romanistici per Maria Zabłocka, eds. Z. BENINCASA, J. URBANIK, Warszawa 2016, p. 1199.

${ }_{21}$ More on iudicium domesticum in E. VolterRA, Il preteso tribunale domestico in diritto romano, «Rivista Italiana per le Scienze Giuridiche» 2/1948, p. 108-153; G. BRINI, Matrimonio e divorzio. Nel diritto Romano, II, Bologna 1888, p. 150-156; W. KunkeL, 
familias who had married his sons in unions involving manus also had the right to the title of mater familias ${ }^{22}$.

There was no obligation for citizens to contract a marriage associated with manus. They could marry without the need for the woman to be subject to the manus of her husband or his pater familias. Her legal status in her agnatic family would then be that of a person alieni iuris, or she would be sui iuris ${ }^{23}$.

Such a possibility was envisaged in the Twelve Tables ${ }^{24}$, as Gaius writes:

G 1,111: Itaque lege duodecim tabularum cautum est, ut si qua nollet eo modo in manum mariti convenire, ea quotannis trinoctio abesset atque eo modo cuiusque anni usum interrumperet. Sed hoc totum ius partim legibus sublatum est, partim ipsa desuetudine obliteratum est.

To forestall her submission to her husband's manus, a woman was required to spend three nights away from the marital home. She had to repeat this procedure every year, because the course of her "usucaption" was renewed at the beginning of each new year ${ }^{25}$. The time she spent out of the marital home was designated for rites performed in her agnatic family, giving her the opportunity to participate in religious ceremonies

Das Konsilium im Hausgericht, «ZSS» 83/1966, p. 219-251; W. MossAKowsкI, 'Iudicium domesticum' w okresie Republiki Rzymskiej, [in:] Rodzina w społeczeństwach antycznych i wczesnym chrześcijaństwie, ed. J. JundzıŁŁ, Bydgoszcz 1995, p. 85-93.

22 Gell. 18, 6, 9: unde ipsum quoque "matrimonium" dicitur, matrem autem familias appellatam esse eam solam, quae in mariti manu mancipioque aut in eius, in cuius maritus, manu mancipioque esset, quoniam non in matrimonium tantum, sed in familiam quoque mariti et in sui heredis locum venisset.; see also E. VOLTERr A, Lezioni..., p. 136; J. ZАвŁOCKI, Rodzina..., p. 48.

23 J. F. Gardner, Women in Roman Law and Society, London and Sydney 1986, p. 45; see also G. Brini, op. cit., p. 68-70; L.CAPogrossi Colognesi, Matrimonium..., p. 66-67; J. ŁUKASIEWICZ, Sytuacja majątkowa matżonków w prawie rzymskim antycznym, «Roczniki Nauk Prawnych»18.2/2008, p. 160.

24 Tab, 6,5; M. ZaвŁockA, J. ZавŁocki, Ustawa XII Tablic. Tekst - tłumaczenie - objaśnienia3, Warszawa 2013, p. 38; B. Albanese, 'Trinoctio abesse' e XII Tavole, «AUPA» 48/2003, p. 24 ff.

25 M. Kaser, op. cit., p. 258; B. Albanese, op. cit., p. 2-6. 
celebrated in her agnatic family, including the festival of the dead ${ }^{26}$, on the grounds that she was still a member of that family.

Gell. 3,2,12-13: Q. quoque Mucium iureconsultum dicere solitum legi non esse usurpatam mulierem, quae, cum Kalendis Ianuariis apud virum matrimonii causa esse coepisset, ante diem IV. Kalendas Ianuarias sequentes usurpatum isset: non enim posse impleri trinoctium, quod abesse a viro usurpandi causa ex duodecim tabulis deberet, quoniam tertiae noctis posteriores sex horae alterius anni essent, qui inciperet ex Kalendis.

It is clear from Gellius' account ${ }^{27}$ that a woman who wanted to keep the legal status she had had hitherto and not come under her husband's manus ${ }^{28}$ had to spend three consecutive nights away from her husband's house. ${ }^{29}$ Gellius points out that an interruption in her usus would not be effective if the last night she spent away from her husband's house was the last night of December/the first night of January. In other words, if she started the three days away from her husband's house on 29 December and returned on the Kalends of January, the trinoctio abesse would not be effective, and in spite of being away for three nights, she would still pass under her husband's manus, because in this situation her period of absence would be six hours short of the time required for an effective interruption of usus.

Gellius writes that if the woman left her husband's house on the last night of December/the first night of January, she would come into her husband's power ${ }^{30}$; however, his remark applies only to marriages

26 M. ZabŁocka, J. ZabŁocki, op. cit., p. 38; see also E. Cantarella, op. cit., p. 446-447; A. WAtson, op. cit., p. 15-17; C. FAYER, op. cit., p. 282.

27 A similar account occurs in Macrob., Sat. 1,3,9: Quintum quoque Mucium iureconsultum dicere solitum legi non esse usurpatam mulierem quae, cum Kalendis Ianuariis apud virum matrimonii causa esse coepisset, a. d. IV. Kalendas Ianuarias sequentes usurpatum isset: non enim posse inpleri trinoctium quo abesse a viro usurpandi causa ex duodecim tabulis deberet, quoniam tertiae noctis posteriores sex horae alterius anni essent qui inciperet ex Kalendis.

28 See D. 41,3,2 for the meaning of the term usurpatio.

29 E. Volterra, La concepion..., p. 3; A. WAtson, op. cit., p 17.

30 C. FAYER, op. cit., p. 277-278; see also H. InSADOWski, op. cit., p. 126-127. 
contracted on $1^{\text {st }}$ January. In my opinion the conclusion to be drawn is that the course of the usus should be calculated individually for each marriage, starting on the day when it was contracted, i.e. on the day when deductio in domum mariti was performed. For instance, if the marriage was contracted on $8 \mathrm{March}$, and the woman was absent from $6 \mathrm{March}$ to $8 \mathrm{March}$, the interruption of usus was ineffective, and she still passed under the manus of her husband, because half of the last night of her absence was counted as belonging to the next year of the marriage, and hence the interruption was six hours short of the time of absence required for an effective interruption of $u s u s^{31}$. For a successful interruption of usus, the woman had to leave the marital home for three consecutive nights, the last of which could not be the night before the anniversary of the marriage. In his passage on the trinoctium Gellius merely used the last night of December / the Kalends of January as an example, which was a frequent literary practice. The time a woman had to spend in her husband's house to put his manus over her into effect was not a calendar year, as it might seem, but a full year of marriage counted from the day on which it was contracted. She could pass under her husband's manus on any of the successive anniversaries of the marriage.

According to Cicero, it was still possible for a woman to avoid passing under her husband's authority despite having spent a full year in his house:

Cic, Pro Flacc. 84: At enim Androni Sextilio gravis iniuria facta est et non ferenda, quod, cum esset eius uxor Valeria intestato mortua, sic egit eam rem Flaccus quasi ad ipsum hereditas pertineret. In quo quid reprehendas scire cupio. Quod falsum intenderit? Qui doces? 'Ingenua,' inquit, 'fuit.' O peritum iuris hominem! Quid? ab ingenuis mulieribus hereditates lege non veniunt? 'In manum,' inquit, 'convenerat.' Nunc audio; sed quaero, usu an coemptione? Vsu non potuit; nihil enim potest de tutela legitima nisi omnium tutorum auctoritate deminui. Coemptione? Omnibus ergo auctoribus; in quibus certe Flaccum fuisse non dices.

31 C. FAYER, op. cit., p. 277-278. 
A woman who was under the authority of a tutor could only be put under the power of her husband on the grounds of an usus if her tutor consented $^{32}$. So a man could not acquire manus over his wife until such time as her tutor issued his consent (auctoritas) ${ }^{33}$. In other words, even after years of uninterrupted cohabitation in her husband's house, a woman could not pass under his manus if her tutor did not issue his consent. This passage shows there was a reservation on the possibility of entering the husband's power by usus for women under the authority of a tutor, and the exceptional situation where, in spite of a year of uninterrupted cohabitation as man and wife, the marriage was still not associated with manus ${ }^{34}$.

Let's now return to Gaius 1,111, where he writes that the institution of usus was abolished, partly by legislation, and partly by falling into disuse. Originally marriages associated with manus were far more common than those in which the woman did not pass under her husband's power ${ }^{35}$. In the opinion of some scholars, in the most ancient times there were no marriages in which the woman was not put under the manus of her husband. However, gradually the institution of manus became less and less popular. By the end of the Republic matrimonia sine manu had become more popular. During the Principate it was rare for a woman to be under her husband's manus, and as a rule this happened when the children of the marriage were to be designated to hold senior sacerdotal offices ${ }^{36}$. Finally, under the Dominate, under the influence of Christianity, the institution became obsolete ${ }^{37}$.

32 More on tutela mulierum in M. ZAвŁocкA, Zanikanie instytucji 'tutela mulierum' w prawie rzymskim, «Prawo Kanoniczne» 30.3-4/1987, p. 240-252; J. E. GrubBs, op. cit., p. 23-34; M. KASER, op. cit., p. 292-293.

33 P. Bonfante, op. cit., p. 66-67.

34 P. Bonfante, op. cit., p. 66-67; see also H. Insadowski, op. cit., p. 126.

35 A. Watson, op. cit., p. 17-18.

36 H. Insadowski, op. cit., p. 141-142.

37 M. ZaвŁoска, 'Confarreatio'..., p. 239-245; see also W. Rozwadowski, 'Manus mariti' in the Light of 'Gaius Institutiones', [in:] Marriage: Ideal - Law - Practice: Proceedings of a Conference Held in Memory of Henryk Kupiszewski, Warszawa 2005, p. 161; M. KuryŁowicz, Wokót istoty.., p. 1145; and J. E. GrubBs, op. cit., p. 21. 
The obsolescence of usus as an institution is to be dated to the period before the Institutes of Gaius, perhaps to the times of Augustus, or more precisely to his marriage legislation ${ }^{38}$. There are no sources which may be used to determine when the institution started, yet it must certainly have been before the Law of the Twelve Tables, which prescribes the trinoctio abesse possibility ${ }^{39}$.

Presumably the institution of usus was modelled on usucaptio ${ }^{40}$, viz. usucaption in property law, whereby the effective bona fide possession of a thing gave the user the right of its ownership ${ }^{41}$. In addition, the same conditions held for an effecitve usus as for usucaptio, viz. the lapse of the prescribed length of time, and uninterrupted possession for that period of time $e^{42}$, which allows us to assume that usus was modelled on usucaptio.

According to C. Fayer, usus was a special case of usucaptio under marriage law ${ }^{43}$. However, I think that this opinion goes too far if formulated in this way, because it would mean that usus was part of property law.

Here we should consider when the institution of trinoctio abesse appeared - did the wife's option to leave the house for three nights and interrupt the course of "usucaption" emerge at the same time as usus? As W. Rozwadowski has observed, usurpatio trinoctii was only brought in by the Law of the Twelve Tables, despite the fact that the Twelve Tables were a reflection of customary law. So we should ask another question: was there a form of usus prior to the Law of the Twelve Tables without the option of usurpatio trinoctii ${ }^{44}$ ?

\footnotetext{
38 C. FAYER, op. cit., p. 278 fn. 297.

39 E.C. Clark, History of Roman Private Law, Cambridge 1919, p. 82-83.

40 I. Piro, 'Usu in manum convenire', Napoli 1994, p. $121 \mathrm{ff}$., holds a different opinion.

${ }^{41}$ H. Insadowski, op. cit., p. 123; see also H. Levy, op. cit., p. 68; and B. Albanese, op. cit., p. 5-7.

42 R. Sонм, Instytucje, historia i system. Rzymskie prawo prywatne, Warszawa 1925, p. 496-497.

43 C. FAYER, op. cit., p. 272-274.

44 R. Sohm, op. cit., p. 497-498; L. Capogrossi Colognesi, op. cit., p. 70-73.
} 
In W. Rzowadowski's opinion, we cannot rule out that usurpatio trinoctii was earlier than the Law of the Twelve Tables, but it was regulated in a different way than in the decemviral legislation, which laid down the period of the wife's absence as three consecutive nights. Rozwadowski showed that the Romans distinguished between manus and marriage, just as they distinguished between ownership and possession. However, in both cases usus played a similar role, so just as with an interruption in the continuity of usucaption, there was a possibility of an interruption in the continuity of "usucaption" in a marital relationship ${ }^{45}$.

In view of this, it is likely that the option to interrupt the continuity of usus pre-existed the Law of the Twelve Tables, which gave the institution its final shape.

Nowadays it is generally held that marriage is a fact, while manus is a legal state, and the distinction is uncontroversial. Yet in the opinion of M. Talamanca and W. Litewski, the Romans did not make a distinction between marriage and manus until around the turn of the 3rd and 2nd century BCE. Moreover, some scholars say that in the most ancient times the concepts of marriage and manus were identical ${ }^{46}$. C. Fayer holds a similar view, namely that prior to the Law of the Twelve Tablets all marriages were cum manu, and that in case of confarreatio and coëmptio the wife came under her husband's manus when the marriage was contracted, but a year later in the case of $u s u s^{47}$. Yet there is an inherent inconsistency in such a view: in an usus marriage the relationship must have lasted for a year as a non-manus marriage before the wife came under the husband's manus.

We may indeed assume that in the most ancient times marriage was always associated with the wife being put under her husband's authority. On this basis we may speculate that usus was a later

45 W. RozwADowski, Istota..., p. 781-782.

46 W. WoŁodkiewicz, Prawo..., p. 137; see also M. Talamanca, Instituzioni di diritto romano, Milano 1990, p. 132 f.; W. LITEWsKi, Rzymskie prawo prywatne, Warszawa 1994, p. 161; D. CiUŁA, Najstarsze przyczyny rozwodu w prawie rzymskim in: Wokół problematyki małżeństwa w prawie rzymskim. Henrico Insadowski (1888-1946) in memoriam, Lublin 2007, p. 55.

47 C. FAYER, op. cit., p. 283-284. 
development. However, it is also possible that all three forms appeared at more or less the same time. Usus may have been important as grounds to provide evidence to distinguish between concubinage and a marriage, particularly significant if the marriage was contracted without the deductio in domum mariti ceremony. We cannot say that usus in itself brought about the contracting of a marriage, yet it could have provided evidence that the man and woman intended to live together on a permanent basis, and hence that their relationship was a marriage, not concubinage. If in the earliest period there had been no legal form to regulate the contracting of marriage, the very fact of the wife coming under the husband's manus would have provided clear proof that the relationship was a marriage.

This view would correspond with the theory I have already mentioned, that prior to the Law of the Twelve Tablets the Romans did not acknowledge the right to interrupt usus. Although such a claim may seem too far-reaching - in my opinion there was a clear distinction between marriage and manus, manifested chiefly in the fact that marriage was a fact whereas manus was a legal state ${ }^{48}$ - nonetheless, in the most ancient times the manus began at the time when the marriage was contracted, except for the case of usus, in which case manus would have started a year after the marriage was contracted. In my opinion, originally the Romans did not acknowledge marriages in which the wife did not enter under the authority of her husband straightaway, so there was no usus. I would emphasise once again that in accordance with Gaius' account, trinoctium abesse was introduced by the Law of the Twelve Tablets, no doubt to cater for needs and expectations. There are no sources to confirm the existence of trinoctium abesse as an institution prior to the Twelve Tablets. Usurpatio trinoctii could have been introduced in response to this tendency, to give couples the opportunity to live as spouses sine manu. Hence usurpatio trinoctii would have arisen only at the time when manus was becoming less widespread, and confarreatio and coëmptio were becoming less and less

48 Currently this is the opinion held by most scholars of Roman law. See W. RozWADOWski, Istota..., p. 778; and likewise M. KuRYŁowICZ, Wokół istoty..., p. 1144. 
frequently practised. However, since usus was derived from usucapio, which offered the option of discontinuing the usucaption, while the Law of the Twelve Tablets was a reflection of customary law, it is highly probable that prior to the Law of the Twelve Tablets, when there would have been no specific provisions for the interruption of usus, the Romans followed the procedure under property law to discontinue usucaption in order to evade the inception of a marriage combined with manus.

A conclusion which could be drawn from an examination of this hypothesis could be that prior to the Law of the Twelve Tablets usus might have been applied as a "usucaption" to "remedy" the legal status of spouses in a marital relationship where for some reason the wife had not been put under her husband's power at the time when the marriage was contracted ${ }^{49}$.

Originally women must have been under the power of a man, usually their grandfather or father, and in adult life their husband or father-inlaw, and their family status was always analogous to that of a daughter. The reason given for this was that women were weaker than men and needed to be protected, which justified the need for usus and other ways in which a woman was put under the power of her husband. Paradoxically, however, once women were given the opportunity to take part in commercial transactions, their business activities contributed to the growth of the economy. As C. Fayer has observed, this phenomenon was particularly prominent during the Punic Wars, when many of the men died and women were forced to take over some of their duties ${ }^{50}$.

To conclude, despite the problems with examining the origins of the institution of usus, we may speculate that it was modelled on usucapio in property law. Hence we may assume that trinoctio abesse was derived from the procedure for the interruption of a usucaption, but the Twelve Tables regulated the practice in a different way for the law on marriage.

\footnotetext{
49

W. RozWAdowski, Istota..., p. 781-782.

50

C. FAYER, op. cit., p. 284-285.
} 
'Usus' JAKO SPOSÓB WEJŚCIA KOBIETY POD WŁADZĘ JEJ MĘŻA

\section{Streszczenie}

$\mathrm{W}$ artykule poruszone zostały kwestie związane z instytucja usus stanowiącą jeden ze sposobów wejścia żony pod władzę męża. Artykuł wejście żony pod władzę męża w formie usus, porusza zagadnienia związane z genezą tejże instytucji. Autor zastanawia się także nad znaczeniem umiejscowienia instytucji usus w źródłach. Podstawowym zagadnieniem badawczym jest wyznaczenie terminu rozpoczęcia biegu usus, zatem pewnego rodzaju „zaużywania czy też zasiedzenia”, a w konsekwencji również zakończenie tego terminu. Ponadto autor porusza kwestie związane z usurpatio trinoctii.

\section{The Usus Marriage as a Way to Put a Woman under the Authority of Her Husband}

\section{Summary}

The article addresses issues relating to the institution of usus, which was one of the ways a woman could be put under her husband's authority and power. One of the points discussed is the origin of this institution. I consider the significance of the location of usus in the source documents. The fundamental question in research on usus is the determination of the date on which a period of usus started, in other words usus was treated as a sort of usucaption, which implied a date on which it would finish. I also discuss issues connected with usurpatio trinoctii.

Keywords: usus; manus mariti; usurpatio trinoctii; marriage; a husband's power and authority over his wife.

Słowa kluczowe: usus; manus mariti; usurpatio trinoctii; małżeństwo; władza męża nad żoną. 


\section{Bibliography}

Albanese B., 'Trinoctio abesse' e XII Tavole, «AUPA» 48/2003, p. 24-30.

BenINCASA Z., 'Deductio in domum mariti' a zawarcie iustum matrimonium «Zeszyty Prawnicze» 13.2/2013, p. 7-24.

Betti E., Diritto romano, I, Padova 1935.

Bonfante P., Corso di diritto romano, I, Diritto di famiglia, Milano 1963.

BRINI G., Matrimonio e divorzio nel diritto Romano, II, Bologna 1888.

Cantarella E., L'usus' e la 'conventio in manum', «Labeo» 41/1995, p. 434-448.

Capogrossi Colognesi L., Matrimonium, manus e trinoctium, [in:] Marriage: Ideal - Law - Practice: Proceedings of a Conference Held in Memory of Henryk Kupiszewski, Warszawa 2005, p. 63-81.

CiuŁa D., Najstarsze przyczyny rozwodu w prawie rzymskim, [in:] Wokół problematyki rozwodu w prawie rzymskim. Henrico Insadowski (1888-1946) 'In memoriam', Lublin 2007, p. 53-71.

Clark C.E., History of Roman private law, Cambridge 1919.

FAYER C., La familia romana. Aspetti giuridici ed antiquari. Sponsalia. Matrimonio. Dote. Parte seconda, Roma 2005.

Ferrini C., Manuale di Pandette, I, Milano 1904.

FIORI R., Materfamilias, «BIDR» 96-97/1993-1994, p. 455-498.

GARDNER J. F., Women in Roman Law and Society, London-Sydney 1986.

Grubbs J. E., Women and the law in the Rome Empire, London-New York 2002.

Hersh K.K., The Roman Wedding. Ritual and Meaning in Antiquity, Cambridge 2010.

INSADOWSKI H., Rzymskie prawo małżeńskie a chrześcijaństwo, Lublin 1935.

Kaser M., Römisches Privatrecht, München 1986.

KolańCzyк K., Prawo rzymskie ${ }^{5}$, Warszawa 2000.

Kunkel W., Das Konsilium im Hausgericht, «ZSS» 83/1966, p. 219-251.

Kunkel W., Mater familias, «RE» 14.2/1930, p. 2183-2184.

KuryŁowicz M., Prawo i obyczaje z starożytnym Rzymie, Lublin 1994.

KuryŁowicz M., Wokót istoty małżeństwa rzymskiego, [in:] 'Finis legis Christus'. Księga pamiątkowa dedykowana Księdzu Profesorowi Wojciechowi Góralskiemu z okazji siedemdziesiątej rocznicy urodzin, II, Warszawa 2009, p. 1141-1153.

Levy E., Hergang der römischen Ehescheidung, Weimar 1925.

LiNDERSKi J., Religious Aspects of the Conflict of the Orders: The Case of confarreatio, [in:] Social Struggles in Archaic Rome. New Perspectives on the Conflict of the Orders, ed. K.A. RaAuflaub, Berkeley 1986, p. 542-559.

Litewski W., Rzymskie prawo prywatne, Warszawa 1994. 
Longo C., Diritto di famiglia, Milano 1934.

ŁUKASIEwICZ J., Sytuacja majątkowa małżonków w prawie rzymskim antycznym, «Roczniki nauk prawnych»18.2/2008, p. 157-171.

Mossakowski W., 'Iudicum domesticum' w okresie Republiki Rzymskiej, [in:] Rodzina w społeczeństwach antycznych i wczesnym chrześcijaństwie, ed. J. JundziŁe, Bydgoszcz 1995, p. 85-93.

Piro I., 'Usu in manum convenire', Napoli 1994.

RozWAdowski W., Istota małżeństwa w starożytnym Rzymie, «Gdańskie Studia Prawnicze»14/2005, p. 773-784.

Rozwadowski W., 'Manus mariti' in the Light of 'Gaius Institutiones', [in:] Marriage: Ideal - Law - Practice: Proceedings of a Conference Held in Memory of Henryk Kupiszewski, Warszawa 2005, p. 161-174.

Rozwadowski W., Prawo rzymskie. Zarys wykładu wraz z wyborem źródet, Warszawa 1991.

RozwADowski W., Zarys wykładu wraz z wyborem źródeł, Warszawa 1991.

Rykaczewski E., Mowy Marka Tulliusz Cycerona. Przekład, II, Paryż-Warszawa-Poznań 1970.

SANNA M.V., Matrimonio e altre situazioni matrimoniali nel diritto romano classico. 'Matrimonium iustum - matrimonium iniustum', Napoli 2012.

Soнм R., Instytucje, historia i system. Rzymskie prawo prywatne, Warszawa 1925.

Talamanca M., Instituzioni di diritto romano, Milano 1990.

Watson A., Studies in Roman Private Law, London 1991.

WoŁodkiewicz W., Attorno al significato della nozione di 'mater familias', [in:] Studi in onore di C. Sanfilippo, III, Milano 1983, p. 735-756.

WoŁodkiewicz W., 'Materfamilias', «CPH» 16.1/1964, p. 103-142.

Volterra E., Il preteso tribunale domestico in diritto romano, «Rivista Italiana per le Scienze Giuridiche» 2/1948, s. 108-153.

Volterra E., La conception du mariage d'après les juristes romanis, Padova 1940.

Volterra E, Lezioni di diritto Romano. Il matrimonio Romano, Rome 1960 - 61.

ZABŁOCKA M., 'Confarreatio' w ustawodawstwie pierwszych cesarzy rzymskich, «Prawo Kanoniczne» 31.1-2/1988, p. 237-246.

ZавŁоска M., Przemiany prawa osobowego i rodzinnego w ustawodawstwie dynastii julijsko-klaudyjskiej, Warszawa 1987.

Zавєоска M., Zanikanie instytucji 'tutela mulierum' $w$ prawie rzymskim, «Prawo Kanoniczne» 30.3-4/1987, p. 240-252. 
ZавŁоска M., ZавŁоскі J., Ustawa XII Tablic. Tekst - Tłumaczenie - Objaśnienia3, Warszawa 2013.

ZавŁоскі J., 'Consensus facit nuptias', [in:] Marriage: Ideal - Law - Practice: Proceedings of a Conference Held in Memory of Henryk Kupiszewski, Warszawa 2005, p. 235-241.

Zавєоскі J., Il concetto di 'mater familias' in caso di arrogazione, [in:] 'Mater familias'. Scritti romanistici per Maria Zabłocka, ed. Z. BENINCAsA, J. URBANiK, Warszawa 2016, p. 1199-1205.

ZaвŁocki J., Rodzina Rzymska w świetle 'Noctes Atticae' Aulusa Gelliusa, [in:] Rodzina w społeczeństwach antycznych i wczesnym chrześcijaństwie, ed. J. JundziŁe, Bydgoszcz 1995, p. 45-51.

ZАвєоскі J., Zgoda małżeńska w prawie rzymskim, [in:] 'Honeste vivere'... Księga pamiątkowa ku czci Profesora Władysława Bojarskiego, Toruń 2001, p. 301-312. 